\title{
Perceived Quality Characteristics Influencing Households' Preference for Local and Imported Rice and Their Effect on Price in the Northern Region, Ghana
}

\author{
Iddrisu Abukari \\ (Corresponding Author) \\ Department of Agricultural and Resource Economics, Nyankpala \\ campus, University for Development Studies, Tamale, Ghana \\ abuiddi10o@gmail.com \\ Samuel A. Donkoh \\ Department of Agricultural and Resource Economics, Nyankpala \\ campus, University for Development Studies, Tamale, Ghana

\section{Dennis Sedem Ehiakpor} \\ Department of Agricultural and Resource Economics, Nyankpala \\ campus, University for Development Studies, Tamale, Ghana \\ DOI//http://dx.doi.org/10.4314/gjds.v16i1.7
}

\begin{abstract}
The study investigates how perceived rice quality characteristics influence household preference for local and imported rice and its effect on prices. A multi-stage sampling technique was used to select 400 rice consuming households from Tamale, Yendi and Savelugu in the northern region. A structured questionnaire was used to interview one consumer (the woman in charge of purchasing and cooking of food) in each household on the quality characteristics that influence their demand for either local rice or imported rice. Rice quality characteristics were ranked with about $71 \%$ agreement in descending order of taste, colour, cleanness, nutrient content, safe health, aroma, grain size, texture and cooking time. The results showed that colour had the highest implicit value of Gh $\phi$ 4.42, followed by taste (Gh\$ 2.66). The rest are cooking time (Gh\$1.39), grain size (Ghф 0.33), impurities (Gh\$-1.08) and texture (Ghф-1.38). These results indicate the importance consumers attach to rice brands on the basis of product characteristics. To encourage the consumption of domestic rice requires that production and processing methods of local rice are improved in order to bring it, at least at par with the qualities of imported rice.
\end{abstract}


Keywords: Hedonic Price Model, Quality Characteristics, Rice Preferences, Implicit Value, Northern Ghana

\section{INTRODUCTION}

The total global rice (Oryza sativa L.) consumption is estimated to be 480.49 million metric tons (Statista, 2019). According to Seck, Tollens, Wopereis, Diagne and Bamba (2010), about $40 \%$ of the rice consumed in Africa is imported. This represents more than $30 \%$ of the total volume of rice traded on the international market. A similar observation has been made by Seck, Diagne, Mohanty and Wopereis (2012) to the effect that these imports converge around 10 million metric tonnes, costing more than US $\$ 5$ billion annually. The implications of the high dependence and huge cost outlays, for national government budgets, necessitate that appropriate steps are taken to substitute imported rice with locally produced rice, especially in countries that have comparative advantage. However, this requires improving the quality characteristics of domestically produced rice to meet preference standards of consumers, since local rice is often not competitive as against imported rice due to the perceived inferior quality.

Rose, Papa, Tebila, and Aliou (2013) also stressed that the increasing rice importation in West Africa significantly undermines the efforts that various governments are making to increase domestic rice production. This therefore calls for strategic measures that could address the quality needs hence marketing difficulties of local rice to reverse this trend for the benefit of local rice producers. To sustain the impact of investments already made in rice production, they recommended that the quality of local rice should compete well with that of imported rice. Thus, Ghana's ability to produce high quality domestic rice brands that meet consumers' preferences could reverse the high consumption of imported rice in Ghana in favour of domestic rice. This in the long run would help restore and stabilise the Ghanaian economy which would engender a great deal of efficient allocation of resources within the economy, increase productivity and guarantee food security. In Ghana, like many other developing countries, rice consumption is second only to maize as a cereal staple. People mention of convenience in cooking rice as a major determinant of its growing popularity and demand in urban towns and cities. However, even though Ghana is self-sufficient in many food crops, this is not the case for rice. For instance, between 2013 and 2015, a total of 593,069 metric tonnes of rice was imported to supplement domestic rice output, which represents $56 \%$ of total rice supplied for consumption (MoFA, 2016).

Tanko (2015) recommended that it may not be appropriate to protect local producers against competition from foreign producers, instead the former should 
be supported through modern processing techniques and tools so that they can also upgrade their produce. He observed that, local producers are not only price takers in the price transmission process, they are also price makers, therefore, they should be placed on equal ground with their foreign counterparts for a healthy competition.

Demont, Rutsaert, Ndour, Verbreke, Seck and Tollens (2012) surveyed some West African countries and found that domestically produced rice could be highly competitive to imported rice if the quality is improved to satisfy consumers' preferences. Therefore, improvements in the intrinsic and extrinsic quality attributes become the focus for developing and strengthening rice value chains in Africa. Specifically, Fofana, Futakuchi, Manful, Bokossa, Dossou and Bleoussi (2011) found that majority of rice consumers in Benin have developed preferences for imported rice over domestically produced rice due to changes in quality characteristics such as presence of impurities, nutritional content and cooking time. A similar study by Diako, Sakyi-Dawson, Bediako-Amoa, Saalia and Man (2010) on consumers' rice preference in Accra also found the presence of impurities and low quality level of domestic rice as the key factors that influence the rice consumption patterns in Ghana.

This study aims to investigate quality characteristics that affect households' preference for various rice brands in the northern region and the effects of this quality attributes on the price of local rice. This is necessary to identify consumers' preferences and quality characteristics that can help inform policy and investment decisions on the type of rice varieties to produce locally.

Quite a number of similar studies have been undertaken both in and outside Ghana. For instance, Demont, Fiamohe and Kinkpe (2017) sought to compare the demand for foreign (Asian rice) and local rice in communities that were close to the port and those that were remote from same. Five West African Urban markets, namely; Dantokpa Market (in Cotonou-Benn); Ouando Market (in Porto-Novo-Benin); Gagnoa Market (in Gagnoa in Cote d'lvoire); Lafia Central market (in Lafia, Nigeria); and Tillabery Market in Tillabery-Niger)., were purposively selected. The findings indicated that the demand for the foreign rice were higher in communities closer to the port while the demand for local rice was also higher in the communities that were farther away from the ports. This implies that it would require more efforts to increase the demand of local rice in communities closer to the ports. Specifically, it would require bringing the local rice up to standards with the foreign rice if the former is to be appreciated. This means unearthing the good characteristics that the foreign rice has over the local rice. Even though Demont et al.'s (2017) study delved into these characteristics, the present study is still important since the 
conditions prevailing in these communities and markets may be different from that of our study areas.

The study by Anang, Adjetey and Abiriwe (2011) is not only old, it was carried out only in Tamale metropolis and did not include Yendi and Savelugu which the present study does. Although Ehiakpor, Apumbora, Danso-Abbeam and Adzawla's (2017) study is relatively recent, it was carried out in the Upper East Region and not in the Northern Region. We have the opinion that the socioeconomic factors, especially consumer preference, are time and location-specific and as such it is important for us to keep updating studies of this nature so that stakeholders can be better informed as to the angle from which local rice production can be promoted.

\section{LITERATURE REVIEW}

\section{Measures to Improve Rice Production in Ghana}

Rice is the second major staple of Ghana. The annual area planted for rice have increased from109,0ooha in 2007 to 236,0ooha in 2016 (MoFA, 2017a). In terms of output, the production output has increased from $185,00 \mathrm{Mt}$ to $688,000 \mathrm{Mt}$ in 2016. Rice production in Ghana is high in the Volta, Northern, Upper East, Eastern and Ashanti regions of Ghana. However, the average production of the country is $2.92 \mathrm{Mt} / \mathrm{ha}$ as against the potential yield of $6 \mathrm{Mt} / \mathrm{ha}$, thus, less than half of the potential yield have been achieved (MoFA, 2017a). Despite the increase in domestic rice production, there is low competitiveness of the domestic rice due to low quality in relation to the imported rice (Addison, Sarfo-Mensah and Edusah (2015).). The increasing per capita income and the changing taste of the increasing population towards foreign products have had a negative effect on domestic rice production over the years. Some local rice producers have been indebted due to the high influx of imported rice into the Ghanaian market (Boansi and Favour, 2015). Nyarko and Kassai (2017) explained that Ghana is food insecure in terms of rice consumption since over $60 \%$ of its rice are imported.

The high importation and import bill on rice has been a major concern for policy makers and successive governments especially following the increased food prices in 2008 (Anglucci, Asante-Poku and Anaadumba, 2013). One of the steps taken was to launch National Rice Development Strategy (NRDS) to double domestic rice production within the period 2010-2018 and also improve upon the quality of domestic rice (Anglucci, Asante-Poku and Anaadumba, 2013.). Other programmes initiated following the 2008 food price hikes were the Fertiliser Subsidy Programme in 2008 and the Block Farm programme in 2009. These steps have made some achievements, although the problem of rice importation is still high and the quality 
of domestically produced rice remains a major concern among consumers. Recently in 2017, the Government of Ghana launched Planting for Food and Jobs (PFJ) programme as a strategic plan to improve agricultural production of crops such as rice in the country (MoFA, 2017b). This programme is expected to increase the production of rice in the country. There is also the Rice Sector Support Project (RSSP) that aimed at supporting the production of lowland rice in the three northern regions and part of Volta region. The project is expected to increase milled rice to about 16,350 metric tonnes in the country.

\section{Rice Consumption in Ghana}

In terms of consumption, Taylor (2017) revealed that rice is the second most important cereal next to maize. However, with rising population, it is expected that this figure would rise to $40 \mathrm{~kg}$ by 2020. Taylor (2017) identified other factors that influence rising demand for rice as follows: Increasing urbanisation, a large and growing expatriate community, a growing entrepreneurial middle class, a rapidly growing tourism sector and an increase in women working outside the home.

Rice is used for a wide range of food products in Ghana and the most common ones include jollof rice, rice balls (Emotuo), Waakye, fried rice and rice with stew. The various rice products are fundamentally different in their appearance and characteristics. The diverse uses of rice in Ghana require quality evaluation according to its suitability for specific use (Al-Hassan, Agbekpornu, and Sarpong (2008). The high consumption of rice in a variety of products makes it an important staple in the diet of the people in Ghana.

Diako et al. (2010) reported of low domestic rice consumption in Ghana, and this could be attributed to limited awareness or knowledge of domestic rice availability, and the quality characteristics associated with it. The implication is that, many consumers in the cities are more familiar with imported rice than domestic rice, which is reflected in their patronage pattern. Prominent among the reasons, consumers do not patronise domestic rice are poor post-harvest handling (which results in the presence of stones and other foreign materials in milled rice), limited access and poor quality of locally produced rice. On the other hand, consumers who patronise domestic rice do so out of preference, perceived good nutritional qualities and relatively low price (Diako et al., 2010). 


\section{Market Integration and Price Transmission in the World Rice Export Markets}

Muthayya, Sugimoto, Montgomery and Maberly, (2014) observed that the global rice market is regarded as small and unstable. The reasons are as follows: First, global rice trade accounts for only $7 \%$ of total output. Second, rice is mostly eaten in the same country where it is produced and so any fall in output results in the price level. The fall in output could be as a result of climate change in areas where production is rain-fed. Third many of the rice producing countries adopt protective mechanism so as to ensure domestic food security and stabilised producer prices and income. Fourth, rice trade is highly segmented by the variety (indica, japonica and aromatic), the degree of processing (paddy, parboiled, brown or white) and the degree of milling (percentage of broken). Muthayya, Sugimoto, Montgomery and Maberly (2014) stressed that the combination of these factors results in instability in volumes and prices of the cereal. This notwithstanding, they observed that since 1994 increases in demand and the liberalisation policies run by most developing countries as well as the Uruguay Round Agreement have led to significant increases in rice trade and consumption.

Market integration is generally defined in terms of the Law of One Price (LOP), which states that-given free trade-arbitrage would equalise prices of the same good in different markets up to the transaction cost (Chen and Saghaian, 2016). In the study by Chen and Saghaian (2016), the objective was to investigate market integration and asymmetric price transmission in the rice export market. They used monthly rice prices from three of the major rice producing countries: Thailand, Vietnam and United States. The method of analysis involved a Johnsen test and the estimation of the threshold error correction model (TECM). They found that export prices in the three countries are cointegrated with Thailand and United States as price leaders and Vietnamese price adjusting faster to long-run equilibrium when it is above its equilibrium level with Thai and U.S. prices. The result, thus, implies there is market integration and competition rather than collusion. On the other hand, Fiamohe et al. (2015) found that the transmission between international and domestic rice prices in many West African markets is one directional or skewed, with increases in international prices being transmitted more rapidly than decreases.

\section{Importance of Product Qualities}

Product attributes or quality evaluation by consumers is due to a number of factors such as situation, knowledge, motivation and involvement (Engel, Blackwell and Miniard 1993). Product attributes and their ratings are of significant interest to producers, marketers, researchers and practitioners, because consumers evaluate 
products based on their attributes prior to making purchase decisions. Therefore, it is on the basis of attributes important to consumers that producers and marketers design their products to withstand market competition. Other attributes may be more salient simply because, the consumer is more familiar or can easily remember or recognise the attributes mentioned in the advertisement hence, making these attributes easily noticed and sticks to the minds of consumers. Therefore, consumers focus on product attributes that are perceived as most important and relevant when deciding on which brand to purchase. This is referred to as determinant attributes (Kotler and Amstrong, 2010).

In order to win the competition in today's market, producers are making efforts to offer good quality products and also provide customers with a favourable environment (Soriano, 2002). This would guarantee a continuous demand for a particular product if the value of the product exceeds the expectation and satisfaction of the customer (Shaharudin, Hassan, Ali, Harun, Jalil and Salleh, 2011). Wong, Emrus, Bashir and Tey (2010) suggested that in future, in order to cope with the changing demands, lifestyles and consumer preference, rice should be made available in different forms such as pre-cooked or instant rice, easy-tocook and ready meal with various packaging. Abdullahi, Zainalabidin and Ismail (2011) report that changes in lifestyle and time constraints on women affect the purchasing behaviour of rice brands in the market. For instance, some women may prefer to eat outside the home rather than preparing food at home.

Tomlins, Manful, Larwer, and Hammond (2005) investigated consumer preferences and acceptability of domestic and imported rice in Ghana and concluded that, consumers' preference for imported rice to domestic rice is very high. They also noted that, wealthier and highly educated consumers in urban areas tend to purchase high quality rice based on their perceived nutritional content. The establishment of the Ghana Rice Inter-Professional Body (GRIB) is one of several attempts by Ghana government to revamp the local rice industry. One of the objectives of GRIB is the quality aromatic rice programme which involves the development of markets for raw milled aromatic rice for larger consumer markets. The main aim of this venture is to select and promote the best domestic aromatic (perfumed) varieties to be grown by farmers to capture the huge market demand for aromatic rice in the country and hence promote the patronage of domestic rice. Some of the domestic aromatic rice varieties currently in Ghana are "Togo Marshall", Ex-Baika", "Aromatic Short", Basmati Pusa" and" Jasmine 85". In order to promote the consumption of locally produced rice, the quality characteristics should match those of the imported brands. There is therefore, the need to have information on the quality perceptions and preferences of consumers for aromatic 
rice as a basis for the improvement of domestic rice varieties (Jo and Marie-Aude, 2012).

\section{METHODOLOGY}

\section{Study Area}

The study was carried out in three large towns (Tamale, Savelugu and Yendi) in the northern region of Ghana because of the high demand for rice in these towns. Tamale is a metropolis and the capital of the northern region, while Yendi is a municipality, the second largest town in the northern region and also the capital of the Dagbon Kingdom. Savelugu, however, is a newly created municipality. Tamale is believed to be one of the fastest growing cities in West Africa, due to the presence of Non-Governmental Organisations (NGO) and financial institutions, among others (Ghana Statistical Service, 2014). The northern region is the largest region in Ghana in terms of landmark, occupying a land area of 70,384 square kilometres $(29.5 \%$ of the total landmark of Ghana) (Ghana Statistical Service, 2013). It shares boundaries with the Upper East and Upper West regions to the north, Brong Ahafo and Volta regions to the south, Togo to the east and Cote d'Ivoire to the west. The land is mostly low lying except in the north-eastern corner with the Gambaga escarpment and along the western corridor. The region is drained by the Black and White Volta Rivers and their tributaries such as the Nasia and Dakar Rivers.

Primary data was collected using structured questionnaire to interview rice consuming households selected based on stratified and simple random sampling methods. First, each of the three towns was stratified as suburb, and the lottery technique was used to select households. Four hundred households were selected and interviewed, consisting of 200 households from Tamale metropolis, and 100 households each from Yendi and Savelugu municipalities. These sample proportions were based on the relative size of the towns. Data collected included information on household socioeconomic characteristics, whether household consume local rice or imported rice, what quality characteristics are influencing household preference, retail prices per bowl of household preferred rice, among others.

\section{Analytical Methods}

\section{Kendall's Coefficient of Concordance}

The Kendall's coefficient of concordance $(W)$ is a measure of the agreements among several judges (respondents) who are assessing a given set of objectives (quality perceptions) (Legendre, 2005). $W$ is an index that measures the ratio of the observed 
variance of the sum of the ranks to the maximum possible variation of the ranks. The idea behind this index is to find the sum of the ranks for each quality perception that has been ranked.

Following Legendre (2005), the Kendall's coefficient of concordance ( $W$ ) is given by the relation;

$W=\frac{12 S}{P^{2}\left(n^{3}-n\right)}-P^{T}$

where

$W=$ Kendall's coefficient of concordance, $P=$ number of respondents ranking the quality characteristics, $n=$ number of quality perceptions, $T=$ correction factor for tying ranks, $S=$ sum of squares statistics over the row sum of ranks $\left(\mathrm{R}_{\mathrm{i}}\right)$, given by

$$
S=\sum_{i=1}^{n}\left(R_{i}-R\right)^{2}
$$

$R$ is the mean of $R_{i}$. The correction factor for tied ranks (T) is also given as:

$$
T=\sum_{k=1}^{m}\left(t_{k}^{3}-t_{k}\right)
$$

$t^{3}$ is the number of ranks in each of $m$ group of ties. The quality characteristics to be ranked are colour, taste, texture, aroma, cooking time, size of grains and impurities. In this study the Kendall's Coefficient of concordance is chosen over the Garrett technique. The latter is normally used with a heterogeneous group, where heterogeneity could be caused by location, ecology or by climatic conditions (Garrett and Woodworth, 1969). In this study, there is no wide variations among the study areas in terms of location, ecology or climatic conditions. The Kendall's Coefficient of concordance has wider applications than the Garett technique

\section{The Hedonic Price Model}

Generally, prices of commodities are determined from two perspectives within a market system. The first is seasonal variation which influences the demand and supply of a commodity. The other determinants of the commodity prices are the quality characteristics embodied in each brand of the same commodity. It is established that market price depends on the quality characteristics of the product such as texture, taste, colour, nutritional content, convenience and packaging.

The Hedonic pricing model was developed by Rosen (1974), who defined hedonic price as the "implicit values or prices of attributes which are revealed to economic agents from the observed prices of various brands of a product based on the number of quality characteristics or attributes associated with the brands". The basic hypothesis is that, goods are valued for their utility-bearing attributes or characteristics, and products 
prices vary with the change in quality characteristics associated with it (Rosen, 1974). Hedonic pricing model is used to determine the effects of commodity quality factors on the market prices.

Hedonic pricing method is widely used to evaluate the impact of quality attributes or characteristics of a commodity on its price (McConnell and Strand, 200o; Carroll, Wopereis, Jones, Lancon, Erenstein and Guei, 2001; Roheim, Gardiner and Asche, 2007; Selim, 2008; Sentürk and Erdem, 2010). The theory of hedonic price is that, the price $(P)$ of a commodity is a function of its characteristics. The model assumes that a product is composed of a variety of specific attributes that consumers value independently. For any given commodity, characterised by the set of $j$-th specific attributes which are denoted as $Z=\left(Z_{1}, Z_{2}, \ldots . ., Z_{j}\right)$, consumer preference for the commodity is assumed to be determined by its corresponding characteristic vector alone, and the functional relation is given by equation 7 below.

$\mathrm{P}=f(Z)$

Given this relationship, the marginal price of the $j$-th characteristic, say $Z_{j}$ is given by the partial derivative of the hedonic function. The hedonic price $P / \partial Z_{j}=\partial f / \partial Z_{j}$ indicates how much the price $(P)$ of good changes if the good is endowed with an additional unit of the characteristic $Z_{j}$, all other things equal. Note however, that the estimated hedonic price function typically identifies neither demand nor supply functions (Rosen, 1974).

Cropper, Leland and Kenneth (1988) raised the argument that, the functional forms have a significant effect on the error terms in measuring marginal attribute of prices. Hence, the parsimonious approach is to use the ordinary least squares (OLS) linear regression, given by equation (9):

$P=\beta_{o}+\sum_{j=1}^{m} \beta_{j} Z_{j}+\varepsilon$

$\mathrm{P}=$ observed price of rice, $\mathrm{Zj}=$ vector of rice quality characteristics, $\beta^{\prime} \mathrm{s}=$ parameter coefficients and $\varepsilon=$ error term. From the literature, the hedonic pricing model has the ability to estimate values, based on concrete choices. Also, the method is flexible enough to be adapted to relationships among other market goods and external factors.

From the literature, the quality characteristics that influence the price of rice include colour, taste, aroma, texture, size of grain and cooking time. Most consumers perceive that rice with a white colour is neat and therefore good and prepared to offer a higher price than a non-whitish colour. Similarly, when consumers perceive that a particular rice brand is tasty, they would offer a higher price for it. Rice with 
a good aroma is also regarded as fashionable, especially among the rich (Anang, Adjetey and Abiriwe, 2011). A good quality rice must also have a good texture after cooking. Also, most consumers prefer the rice brands with long grains to those with short or broken grains. Furthermore, a rice type with a relatively short cooking time is preferred to the one that takes a long time. A rice type that is devoid of impurities or foreign matter is preferred to those that have such foreign matters.

The empirical version of equation (8) in this study is as follows

$P i=b_{1} X_{i}+b_{2} X_{i}+b_{3} X_{i}+b_{4} X_{i}+b_{5} X_{i}$

$P=$ observed market price of rice brand per bowl $(2.5 \mathrm{~kg})$ and the rest to the right hand side of the equation are the explanatory variables (rice quality characteristics) as follows: $Z_{1}=$ colour; $Z_{2}=$ taste; $Z_{3}=$ aroma; $Z_{4}=$ texture; $Z_{5}=$ size of grain; $Z_{6}=$ cooking time; and $Z_{7}=$ impurities. The rest of the variables are as defined. The description and a priori expectations of the variables are given in Table 1.

The suspicion of possible correlation among the various quality characteristics in the regression necessitates the testing for the presence of multicollinearity in the data. The use of too many dummy variables (which are either zero or one) is a typical cause for exact multicollinearity (Verbeek, 2004). Therefore, a test of the presence of multicollinearity was done using variance inflation factors (VIF).

Table 1: Dummy explanatory variables

\begin{tabular}{|l|l|}
\hline Variable & Description \\
\hline Colour & Dummy; 1 if white and zero otherwise \\
\hline Taste & Dummy; 1 if tasty and zero otherwise \\
\hline Aroma & Dummy; 1 if perfumed and zero otherwise \\
\hline Texture & Dummy; 1 if sticky and zero otherwise \\
\hline Size of grain & Dummy; 1 if long grain and zero otherwise \\
\hline Cooking time & Dummy; 1 if cooking time is short and zero otherwise \\
\hline Impurities & Dummy; 1 if rice has impurities and zero otherwise \\
\hline
\end{tabular}

\section{RESULTS AND DISCUSSION}

\section{Households' Perceived Characteristics of a Quality Rice Brand}

The results of Kendall's W are presented in Table 2, which shows that, taste is the highest preferred rice quality characteristic, with a mean rank of 1.62. This value shows that, the taste grade of rice brand will influence households' demand level. 
Besides taste, colour is also the next preferred rice quality characteristic influencing household demand for a particular rice brand, with a mean rank of 2.72. Cleanness of rice (measured by the absence of stones and other foreign materials) follows next with a mean rank of 3.11. Texture of rice after cooking and cooking time were the two least ranked or lowest preferred quality characteristics, and thus have very little influence on households' demand for a particular rice brand. The value of $\mathrm{W}$ (0.714) was highly significant at 1\% significance level, and implies a high level of agreement among the respondents in ranking the rice quality characteristics.

The Kendall's W results are similar to that of Anang et al. (2011) which show that, taste is ranked as the first quality characteristic preferred by rice consumers in the Tamale metropolis. To determine the quality attributes influencing consumers' preference for cooked rice in Accra, Diako et al. (2010) found that taste was ranked first, and that consumers would want to purchase rice brands that taste nice after cooking to increase consumption. A related study by Danso-Abbeam, Mubarik and Francis (2014) revealed that, taste has $12 \%$ probability to influence consumers' preference for local rice in the Tamale Metropolis.

Table 2: Rank of quality characteristics of rice

\begin{tabular}{|l|l|l|}
\hline Quality Characteristics & Mean Rank & Rank \\
\hline Taste & 1.62 & $1^{\text {st }}$ \\
\hline Colour & 2.72 & $2^{\text {nd }}$ \\
\hline Cleanness & 3.11 & $3^{\text {rd }}$ \\
\hline Nutrient content & 3.96 & $4^{\text {th }}$ \\
\hline Safe health & 4.93 & $5^{\text {th }}$ \\
\hline Aroma & 5.85 & $6^{\text {th }}$ \\
\hline Grain size & 7.12 & $7^{\text {th }}$ \\
\hline Texture & 7.83 & $8^{\text {th }}$ \\
\hline Time used in cooking & 7.88 & $9^{\text {th }}$ \\
\hline
\end{tabular}

$\mathrm{N}=400$, Kendall's W=0.714 Chi-Square=2284.331 Sig. $<0.001$

\section{Rice Quality Characteristics and Price}

Commodity pricing formula takes into account the quality traits possessed by a particular commodity because quality traits form the basis of consumers' purchasing decisions. According to Horna, Smale and Von Oppen (2005), grain quality is one of the key selection criteria commonly used by farmers and consumers to choose a rice brand for production or consumption. Therefore, variation in rice brand prices is justifiable due to the differences in the number of quality characteristics possessed by various rice brands. 
From Table 3, colour has the highest implicit value, meaning that consumers put a high premium on the white colour and therefore are willing to pay a higher price for a rice brand that is very white in appearance. This is evidenced by the higher prices of rice brands that are normally white in colour in the market. Most of these brands are imported rice. Among the domestic rice brands, the "Bolga rice" which is whiter relative to the "Dagomba rice", costs higher. The fact also remains that, many consumers associate high quality of rice brand with whiteness, hence their willingness to pay high premium for white colour. This finding supports that of Ehiakpor et al. (2017) and Rose et al. (2013).

Following colour is the taste of a rice brand, with a coefficient of 2.66 , which is significant at $1 \%$ significance level. This means that the implicit price associated with taste as a quality characteristic is $\mathrm{Gh} \$ 2.66$. In other words, the price of a tasty rice brand could be Gh $\$ 2.66$ more than a stereotyped non-tasty, ceteris paribus. The implicit value of taste shows that consumers are also willing to pay a relatively high premium for very tasty rice brands. This actually reflects the true situation in the open market, where rice brands such as 'Chicago Texas', Ruby brands', 'Royal feast' and 'Sultana', are perceived to be very tasty, and hence command high demand and price compared to other brands. It is interesting to note that taste is the highest preferred rice quality characteristic based on the Kendall's ranking in Table 2. However, it attracted a smaller implicit price relative to colour, which was ranked second but tops in terms of the implicit price levels. This is plausible since colour is an explicit quality attribute that is visible at the point of purchase. This means that value for money in terms of colour is guaranteed compared to taste, which can only be realised during eating, and which cannot be guaranteed at the point of purchase. This finding partly agrees with that of Anang et al. (2011) in Tamale, where taste was also ranked as the highest preferred. Their results however differ with respect to the implicit price determination; not only did Anang et al. (2011) had a far lower taste coefficient (o.069), the variable was also not significant. From the field survey however, consumers perceive that local rice is more nutritious than foreign rice.

Aroma had a significant positive coefficient of 1.99 at $1 \%$ significance level, and indicates the contribution of aroma to the price of a rice brand that is aromatic (perfumed). This means that the proportion of price per $2.5 \mathrm{~kg}$ of rice that is aromatic is Gh\$1.99. Therefore, holding all other quality characteristics constant, the aromatic rice brand is expected to cost higher than non-aromatic rice brand by $G$ h $\$$ 1.99. The relatively high implicit value associated with the aroma as quality characteristic shows its importance in determining the choice of a rice brand. In the real market situation, the aromatic rice brands popularly called "perfumed rice" (e.g., sultana, royal feast, etc.) are the highest priced brands. This finding confirms 
the study of Diako et al. (2010) which concluded that taste and aroma were the highest quality factors influencing consumers' demand for cooked rice.

Cooking time is significant at $1 \%$ significance level with a coefficient of 1.39 , which means that the proportion of rice price per bowl that could be attributed to cooking time is Gh 1.39. Thus, ceteris paribus a rice brand that cooks in a shorter time period costs more than a brand that cooks in a relatively long time by Gh $\$ 1.39$. The time used in cooking is also very essential to consumers because the rising demand and consumption of rice is partly attributed to the convenience of rice in terms of less time spent in preparing it for meals compared to the time spent to prepare traditional meals such as "tuo-zaafi". Therefore, consumers are willing to pay higher premium for rice brands characterised by short cooking time. The finding is consistent with that of Tomlins et al. (2005) and WARDA (2008) who argued that rice is becoming a staple food item in Ghana and Africa widely due to its convenience in cooking. Odusina (2008) discovered that 85\% of respondents' preferred imported rice based on the taste, neatness and quick cooking potentials compared to the locally produced rice brands.

Texture has rather a negative coefficient with a value of -1.38, which implies that, if a rice brand is sticky after cooking, it has a negative implicit value of $\mathrm{Gh} ₫-1.38$. Therefore, all other factors held constant, consumers are willing to pay Gh $\$ 1.38$ more for a rice brand that is not sticky than a rice brand that has sticky texture.

The coefficient is significant at $5 \%$. The texture coefficient met the a priori expectation since many consumers do not like rice brands that are sticky after cooking, and would therefore pay less for such a quality characteristic. There is a general perception which was confirmed by many of the respondents that sticky rice brands do not even have the expanding capacity during cooking. Such brands that do not expand during cooking makes them not preferable because they get used up quickly. Additionally, it is perceived that sticky rice is not delicious. Therefore, as indicated earlier on, consumers are more willing to pay a premium for rice brands where the grains remain non-sticky after cooking, since consumers believe that such brands can swell up and are delicious.

The coefficient of the "Impurities" variable met the negative a priori expectation, with a value of -1.08 but only marginally significant at $10 \%$ level. This implies that holding all other factors constant, the price of a rice brand with impurities such as stones would be lower than the price of a similar brand without impurities by $\mathrm{Gh}$ 1.08. This is plausible because the cleanness or neatness of a product influences consumers' preferences positively, and increases the market value of that product. It was expected that impurities would attract high (negative) premium since much 
of the argument made by the general public for the high preference and demand for imported rice at the expense of local rice is based on the fact that local rice brands contain many stones and foreign materials. Against this expectation, the findings are that impurities had low implicit value among all the quality characteristics considered in this study, except grain size, which was not significant.

The intercept coefficient of 6.19 indicates that, a rice brand without all the above quality characteristics (e.g. not white, non-aromatic, less tasty) is expected to be priced at Gh\$ 6.19 per $2.5 \mathrm{~kg}$ bowl. This means that holding all other factors constant, a bowl of rice (equivalent to $2.5 \mathrm{~kg}$ ) will be sold at $\mathrm{Gh} \pitchfork$ 6.19. If the general perception of matching price with quality level is taken into consideration, then, price per bowl (2.5kg) of the lowest quality rice brand was sold at Gh $\$ 5$ because, that was the least price per bowl recorded during the data collection. This means that, the price difference between the model predicted price of Gh $\$ 6.19$ and the market price of Gh\$5 per bowl of the same quality level is not much. Therefore, the result of the sampled population is $99 \%$ representative of the true characteristics of the entire population in the study area. It is worth mentioning that the F-statistic of 82.2 is significant at $1 \%$ significance level, and means that all the quality characteristics jointly influence the price of rice brand. The quality characteristics are able to explain about $60 \%$ of the variation in the price of rice brand given that the R-Squared value is 0.5948 .

Table 3: Effects of rice quality characteristics on price

\begin{tabular}{|l|l|l|l|l|}
\hline Variable & Coefficient & Std. Error & T & Significance \\
\hline Colour & 4.423581 & 0.781403 & 5.66 & $<^{* 0.001^{* * *}}$ \\
\hline Aroma & 1.993828 & 0.580903 & 3.43 & $0.001^{* * *}$ \\
\hline Taste & 2.661419 & 0.841261 & 3.16 & $0.002^{* * *}$ \\
\hline Texture & -1.379531 & 0.603788 & -2.28 & $0.023^{* *}$ \\
\hline Size of grain & 0.331284 & 0.588369 & 0.56 & 0.574 \\
\hline Cooking time & 1.392689 & 0.535862 & 2.60 & $0.010^{* *}$ \\
\hline Impurities & -1.0784446 & $0 . .640968$ & -1.68 & $0.093^{*}$ \\
\hline Constant & 4.712426 & 1.052336 & 10.66 & $<0.001^{* * *}$ \\
\hline Dependent Variable: Price per 2.5kg bowl & Number of Observations & 400 \\
\hline F-Statistic & 82.21 & F Significant Level & $<0.001$ \\
\hline R-Square & 0.5948 & Adj R-Square & 0.5876 \\
\hline
\end{tabular}

${ }^{* * *},{ }^{* *}$ and ${ }^{*}$ denote significance at $1 \%, 5 \%$ and $10 \%$ levels respectively 


\section{CONCLUSIONS AND RECOMMENDATIONS}

The high degree of agreement among the respondents in ranking quality characteristics indicates consumers' demand or preference for high quality rice, which is the reason for households' high preference for imported rice in the study area and Ghana at large. This is undisputable, as imported rice brands possess many superior quality characteristics such as whiteness, better taste, aromatic and long grain. The findings imply that farmers would benefit from high prices if they produce high quality rice brands since each quality attribute possessed by a rice brand increases its market value. Therefore, the continuous production of domestic rice brands that are not quality competitive to the imported rice would not be in the interest of farmers and the nation as a whole since such rice brands do not meet the quality expectations of the increasing rice consumers. Producing high quality rice brands which would meet the preference of consumers and can also be competitive to the imported rice in the domestic markets would help change this consumption pattern in favour of domestic rice. This would make rice production profitable to farmers and also save the country the millions of dollars spent on rice imports.

Government and private commercial farmers should prioritise the production and supply of high quality rice domestically that can very well compete quality-wise with imported rice, since consumers have preference for high quality rice brands in the local markets. Government should make adequate investment in agricultural research institutions for the development of new rice varieties of high quality that can meet consumers' preference, and can also compete with imported rice in the world market. The Ministry of Food and Agriculture (MoFA) should intensify extension services to educate farmers on the importance or the contribution of individual quality characteristics to the price of rice brands, as attractive price motivates farmers to engage in rice production. MoFA, in collaboration with the research institutions, could purchase appropriate farming and processing technologies that enhance the production and processing of high quality rice at lower cost so that domestic rice can compete effectively with the imported rice in domestic markets.

The findings point to the relevance of quality as a broad factor skewing households' rice preferences towards imported rice. Therefore, to encourage the consumption of local or domestically produced rice, urgent measures need to be engaged for improving the quality standards of the local rice brands to meet the quality preference levels of consumers. The results might be useful for breeders and policy makers in the on-going strives to improve the competitiveness of local rice in Ghana specifically and Africa at large from both quality and price perspectives. Future 
studies can therefore focus on developing rice varieties that possess the preferred qualities confirmed by this study.

\section{References}

Abdullahi, F., Zainalabidin, M. and Ismail, A. (2011). The influence of sociodemographic factors and product attributes on attitudes toward purchasing special rice among Malaysian consumers. International Food Research Journal, 18(3), pp. 1135-1142.

Addison M., Sarfo-Mensah P. and Edusah S. E. (2015). Assessing Ghana's initiative of increasing domestic rice production through the development of rice value chain. Global Journal of Agricultural Economics, Extension and Rural Development, 3(4), pp. 230-237.

Al-Hassan, R., Agbekpornu, H. and Sarpong, D. (2008). Consumer preferences for rice quality characteristics in Accra and the effects of these preferences on price. Agricultural and Food Science Journal, 7, pp. 575-591.

Anang, B., Sidney, N.A. and Abiriwe, S.A. (2011). Consumer preferences for rice quality characteristics and the effects on price in the Tamale Metropolis, Northern Region, Ghana. International Journal of AgriScience, 1(2), pp. 67 - 74.

Anglucci F., Asante-Poku A. and Anaadumba P., 2013. Analysis of incentives and disincentives for rice in Ghana. Technical notes series, MAFAP, FAO, Rome.

Balamurugan P. and Balasubramanian V. (2017). Challenges and opportunities for increasing rice production in sub-Saharan Africa. Journal of Innovative Agriculture, 4(2), pp. 1-10.

Boansi D. and Favour R. M. (2015). Why the persistent increase in Ghana's rice imports? Prescriptions for future rice policy. Asian Journal of Agricultural Extension, Economics and Sociology, 7(4), pp. 1-21.

Carrol, T., Wopereis M,C. Jones, M., Lancon, F., Erenstein, O., and Guei, R. (1213 Febuary, 2001). Challenges and technical opportunities for rice-based production systems for food security and poverty alleviation in sub-Saharan Africa. Proceedings of FAO Rice Coference. Rome, Italy.

Chen and Saghaian (2016) market integration and price transmission in the world Rice export markets Journal of Agricultural and Resource Economics, 41(3), pp. $444-457$.

Cropper, M.L., Leland, B. and Kenneth, E. (1988). On the choice of funtional form for hedonic price functions. Review of Economics and Statistics, 70(4), pp. 668-675. 
Danso-Abbeam, G., Mubarick, A. and Francis, B. (2014). Determinants of consumer preference for local rice in Tamale Metropolis, Ghana. International Journal of Educaton and Social Science, 1(2).

Demont, M., Fiamohe, R. and Kinkpe, T. (2017). Comparative advantage in demand and the development of rice value chains in West AfricaWorld Development, 96, pp. 578-590

Demont, M., Rutsaert, P., Ndour, M., Verbeke, W., Seck, P.A. and Tollens, E. (2012). Experimental auctions, collective induction and choice shift: willingness-topay for rice quality in Senegal. European Review of Agricultural Economics, 1-26.

Diako, C., Sakyi-Dawson, E., Bediako-Amoa, B., Saalia, F. and Man, J. (2010). Consumer perceptions, knowlegde and preferences for aromatic rice types in Ghana. Nature and Science, 8(12).

Ehiakpor, D.S., Apumbora, J. and Danso-Abbeam, G. (2017). Households' preference for local rice in the Upper East region, Ghana. Advances in Agriculture. Article ID 1812975, https://doi.org/10.1155/2017/1812975, 1-9.

Engel, J., Blackwell, R. and Miniard, P. (1993). Consumer behavior (Seventh edition). Orlando, Florida: The Dryden Press.

Fiamohe, R., Alia, D.Y., Bamba, I., Diagne, A. and Amovin-Assagba, E. (2015). Transmission of rice prices from Thailand into West African markets: the case of Benin, Mali, and Senegal. Journal of African Business, pp. 128 - 143.

Fofana, M., Futakuchi, K., Manful, J., Bokossa, Y.I., Dossou, J. and Bleoussi, R. (2011). Rice grain quality: A comparison of imported varieties, local varieties with new varieties adopted in Benin. Food Control 22 , pp. 1821-1825.

Garrett, H.E. and and Woodworth, R.S. (1969) Statistics in Psychology and Education Bombay: Vakils, Feffer and Simons Pvt.Ltd.

Ghana Statistical Service (2014) 2010 Population and Housing Census. District Analytical report. Tamale Metropolis. Accra, Ghana

Ghana Statistical Service (2013) 2010 Population and Housing Census. National Analytical Report. Accra, Ghana.

Horna, J., Smale, M. and Oppen, M. (2005). Farmers' willingness to pay for seedrelated information: rice varieties in nigeria and benin. International Food Policy Research Institute. Washington D. C, U.S.A.

Jo, C. and Marie-Aude, E. (2012). Marketing and quality assurance, essential keys to rice production increases in Ghana. Analysis Centre for studies and strategic foresight. No 52. October. Retrieved from: file://C:/Users/user/Downloads/ Documents/analyse521210anglais.pdf 
Kotler, P. and Armstrong, G. (2010). Principles of marketing, (Thirteen Edition). New Jersey, NJ: Pearson Prentice Hall.

Legendre, P. (2005). Species Association: Kendall's coefficient of concordance revised. Journal of Agriculture, Biological and Environmental Statistics, pp. 226 - 245.

McConnell, X. and Strand, J. (2000). African smallholder farmers: rice production and sustainable livelihoods. International Rice Commission Newsletter (FAO), pp. 33-42.

MoFA. (2016). Agricultural Sector Progress Report. Ghana: Ministry of Food and Agriculture.

MoFA (2017a). Agriculture in Ghana: facts and figures, 2016. http://mofa.gov.gh/ site/wp-content/uploads/2018/o5/Agric\%20in\%20Ghana\%20FandF\%202016_ Final.pdf

MoFA (2017b). Planting for food and jobs: strategic plan for implementation (2017- 020). http://mofa.gov.gh/site/wp-content/uploads/2018/o3/PFJ\%20 document\%20New\%2oNew.pdf

Muthayya, S., Sugimoto, J.D., Montgomery, S and Glen F. Maberly, G.F (2014) An overview of global rice production, supply, trade, and consumption Ann. N.Y. Acad. Sci. 1324 (2014) 7-14C doi: 10.1111/nyas.125407Th

Nyarko D and Kassai Z. (2017). High rice import as a threat to food security and a hindrance to sustainable rice production in Ghana. Archives of Current Research International, 7(2), 1-13

Odusina, O.A. (2008). Urban rice demand analysis: a case study of Ijebu Ode township. Middle-east. Journal of Scientific Research , 3(2): pp. $62-66$.

Roheim, C.A, Gardiner, L. and Asche, F (2007). Value of brands and other attributes: hedonic analysis of retail frozen fish in United Kingdom. Marine Resource Economics, 22, pp. 239-253.

Rose, F., Papa, A.S., Tebila, N. and Aliou, D. (2013). Assessing the effect of consumer purchasing criteria for types of rice in Togo: A choice modelling approach. Hammamet, Tunisia.

Rosen, F. (1974). The role of marketing in present-day ghanaian agriculture: in proceedings of USAID, Ghana 8th Annual Agriculture Conference. USAID Misssion Ghana. Accra.

Seck, P.A., Tollens, E.F., Wopereis, M.C., Diagne, A. and Bamba, I. (2010). Rising trends and variability of rice prices: Threats and opportunities for sub-Saharan Africa. 
Seck, P., Diagne, A., Mohanty, S. and Wopereis, M. (2012). Crops that feed the world 7: rice. Food Security. 4, pp. 7-24.

Selim, D. (2008). Global food security response: ghana rice study. Attachment 1 to the global food security response, West African rice value chain analysis.

Senturk, D. and Erdem, J. (12-13 Febuary, 2010). Changing structure, conduct and performance of the world rice market. Proceedings of FAO Rice Conference. Rome, Italy.

Shaharudin, M. R., Hassan, A. A., Salleh, M. M., Ali, S. M., Harun, E. H., Jalil, M. A., and Abdul, N. A. (2011).. The relationship between extrinsic and intrinsic attributes of product quality with brand loyalty on malaysia national brand motorcycle/scooter, MODENAS. Interdisciplinary Journal of Contemporary Research in Business, 2(9), pp. 135-149.

Soriano, D.R. (2002). Customers' expectations factors in restaurants.The situation in Spain. International Journal Quality and Reliability Management, 19(8/9), pp. 1055-1067.

Statista (2019) Total global rice consumption from 2008 to 2019. Retrieved from https://www.statista.com/statistics/255977/total-global-rice-consumption/

Tanko, M. (2015). Effects of rice importation on the pricing of domestic rice in Northern Region of Ghana.

Taylor, J, (2018) Ghana grain and feed report, global agricultural information Network (GAIN) Retrieved from https://gain.fas.usda.gov/Recent\%20GAIN\%20 Publications/Grain 2oand\%2oFeed\%2oAnnual_Accra_Ghana_4-5-2018.pdf

Tomlins, K., Manful, J., Larwer, P. and Hammond, L. (2005). Urban consumer preferences and sensory evaluation of locally produced and import rice in West Africa. Food quality and preference,. 16, pp. 79-89.

Verbeek, M. (2004). A guide to modern econometrics. John Wiley and Sons Ltd.

WARDA. (2008). Rice trends in Sub-Saharan Africa. andAfrica Rice Center. Cotonou, Benin: WARDA.

Wong, L., Emrus, S., Bashir, B. M. and Tey, Y.S (2010). Malaysia padi and rice industry: applications of supply chain management approach. National Rice Conference. Lumut: National Rice Conference. Swiss Garden Golf Resort, Lumut. 